$$
\begin{gathered}
\text { 서울시 유아숲체험 장의 공간 개선 방안 } \\
\text { 김민정" · 정욱주"** } \\
\text { "국토연구원 도시연구본부 연구원·"서울대학교 조경·지역시스템공학부 교수 }
\end{gathered}
$$

\title{
The Design Improvement Plan of Seoul Forest Visitor Centers for Little Children
}

\author{
Kim, Minjung ${ }^{*}$ Jeong, Wookju ${ }^{*}$ \\ *Researcher, Urban Research Division, Korea Research Institute for Human Settlement \\ "*rofessor, Dept. of Landscape Architecture and Rural Systems Engineering, Seoul National University
}

\begin{abstract}
The Forest Visitor Centers for Little Children who means preschoolers is an educational facility that achieves holistic growth by experiencing forests, and it should not be completed by installing specific facilities in the forest environment, but should be a space where preschoolers can play freely in the forest environment themselves. This study comprehensively evaluated the current status of Seoul Forest Visitor Centers for Little Children and suggested space improvement measures to enhance the effectiveness of forest experience. Through the theoretical review, seven spatial elements that enhance the effect of forest experience and six areas composing outdoor play areas were derived to prepare an analysis table for current status evaluation, and field survey studies were conducted on 24 centers in Seoul. Through expert interviews, the physical status was examined from the perspective of childhood education and the experiences of the users were summarized. As a result of the study, the Seoul Forest Visitor Center for Little Children is classified into six types according to the location characteristics and spatial structure, and has the characteristics of each type. The effectiveness of forest experience can be enhanced by identifying and revealing the environmental strengths of individual centers. In the case of outdoor experience learning zones, the proportion of exercise play areas was very large. By evenly organizing the forest experience space for each area, it will be possible to provide more diverse experiences to preschoolers. However, the status of uniform facility-oriented cannot be viewed as a fragmentary factor that lowers the effect of forest experience. The key to increasing the effect of forest experience by inducing creative activities is the spatial composition that considers the surrounding natural environment. Facilities should be a medium to help preschoolers' interest move into the forest. This study prepared data to understand the average physical status of the Seoul Forest Visitor Center for Little Children and suggested space improvement measures to increase the effectiveness of forest experience. This can be used as basic data for research to improve the quality level of the Seoul Forest Visitor Center for Little Children about 10 years after the project was implemented.
\end{abstract}

Key Words: Field Survey, Spatial Elements, Medium, Facility Arrangement, Environmental Characteristics

Corresponding author: Wookju Jeong, Professor, Dept. of Landscape Architecture and Rural Systems Engineering, Seoul National University, Seoul 08826, Korea, Tel.: +82-2-880-4883, E-mail: wookju@snu.ac.kr 


\section{국문초록}

유아숲체험장은 유아가 산림을 체험함으로써 전인적 성장을 이루는 교육 시설이며, 숲이라는 환경에 특정 시설이 설치됨으로써 완성되는 것이 아니라 숲이라는 환경 자체에서 유아가 자유롭게 놀이할 수 있는 공간이 되어야 한다. 본 연구는 서울시 유아숲체험장의 현황을 종합적으로 평가하여 숲체험 효과를 높이기 위한 공간 개선 방안을 제시하였다. 이론 고찰을 통해 숲체험 효과를 높이는 공간 요소 7가지와 실외놀이공간을 구성하는 6 가지 영역을 도출하여 현황 평가를 위한 분석 표를 작성하고 서울시 유아숲체험장 24 곳을 대상으로 현장조사연구를 수행하였다. 또한 전문가 인터뷰를 통해 유아교육학 관점에서 물리적 현황을 살펴보고 이용 주체의 경험을 정리하였다. 연구 결과 서울시 유아숲체험장은 위치적 특성과 공간 구조에 따라 6 가지 유형으로 분류되며 각 유형별 특징을 갖는다. 개별 유아숲체험장의 환경적 강점을 드러냄으로써 숲체험의 효과를 높일 수 있다. 야외체험학습장의 경우 운동놀이 영역의 비중이 가장 컸다. 영역별 체험 공간을 고르게 구성함으로써 유아에게 보다 다양한 경험을 제공할 수 있다. 그러나 획일적인 시설물 위주의 현황을 숲체험 효과를 낮추는 단편적인 요인으로 볼 수는 없다. 창의적인 활동을 유도하여 숲체험 효과를 높이는 핵심은 주변 자연환경을 고려한 공간 구성이다. 시설물은 유아의 관심이 숲으로 옮겨가도록 돕는 매개체가 되어야 한다. 본 연구는 서울시 유아숲체험장의 평균적인 물리적 현황을 파악할 수 있는 자료를 작성하였고, 숲체험 효과를 높이기 위한 공간 개선 방안을 제시하였다. 이는 사업시행 약 10 년이 지난 시점에서 유아숲체험장의 질적 수준 향상을 위한 연구의 기초 자료로 활용될 수 있다.

주제어: 현장조사, 공간요소, 매개체, 시설 배치, 환경적 특징

\section{I. 서론}

\section{1. 연구 배경}

유아 숲체험에 대한 관심은 2000년대 초 독일의 숲유치원이 국내에 소개되면서 시작되었다. 숲유치원이란 유아가 유치원 건물이 아닌 숲으로 통학하는 유아교육기관의 하나로 숲유치 원의 유아는 흙, 돌멩이, 나뭇잎 등과 같은 자연물을 가지고 자 유놀이를 한다(Seo, 2015). 유아는 숲에서 크고 작은 난관을 스 스로 극복하며 숲으로부터 모든 감각기관이 적절한 자극을 받 아 발달된다(Lee, 2003). 유아는 숲체험을 통해 신체 - 언어 정서·사회성·창의력 등 전인적 성장을 이룬다.

산림청은 유아 숲체험의 활성화를 위해 2012년「산림교육의 활성화에 관한 법률(이하 산림교육법)」을 제정하고, 2014년 「산림교육 활성화를 위한 유아숲체험원 조성·운영 매뉴얼 (이하 매뉴얼)」을 발표하여 유아숲체험원의 조성과 운영에 대한 기준을 마련하였다. 매뉴얼에 따르면 유아숲체험원은 법 적 정의'의 '시설'이라는 표현보다 '공간'에 가까운 개념으로, 유아가 맘껏 뛰놀고 교감하는 숲, 인공 시설 위주가 아닌 체험 활동 위주의 공간, 규칙과 통제를 최소화하는 자유로운 공간과 프로그램을 지향한다. 유아숲체험원은 숲이라는 환경에 특정 시설이 설치됨으로써 완성되는 것이 아니라 숲이라는 환경 자 체에서 유아가 자유롭게 놀이하는 공간이 되어야 한다.

지자체 중 가장 활발하게 유아숲체험장르를 조성 및 운영하
는 서울시는 시설 위주로 조성된 현황에 문제의식을 가지고 있 다. 서울시는 2017년 4월 "초기 유아숲체험장이 시설물 위주였 다면 앞으로는 숲 자체를 교육의 장으로 삼아 동네마다 크고 작은 숲을 발굴해 아이들을 위한 공간으로 조성하겠다"고 발표 했으며, 2019년 3월 "아이들이 숲에서 마음껏 뛰어놀 수 있도 록 다양한 형태의 유아숲 체험시설을 조성해 나가겠다.”고 발 표하였다(https://www.seoul.go.kr/news/news_report.do\# view/204216; www.latimes.kr/news/articleView.html?idxno= 32175). 서울시는 2023년까지 유아숲 400개를 조성할 계획이다. 유아에게 더 많은 숲체험 기회를 제공하기 위한 양적 확대와 더불어 숲체험 효과를 높이기 위한 질적 수준의 향상이 필요하 다. 숲체험의 핵심은 유아가 숲과 교감하는 과정에 있다. 질적 수준 향상을 위해 시설 위주로 조성된 현황에 대한 점검이 필 요하다.

\section{2. 연구 목적}

서울시 유아숲체험장은 공공 산림교육시설로서 모든 유아가 숲체험을 통해 전인적 성장을 이룰 수 있도록 양질의 기회를 제공해야 한다. 본 연구는 서울시 유아숲체험장의 공간 개선 방안을 제시하기 위하여 숲체험 효과를 높이는 공간에 대한 고 찰과 서울시 유아숲체험장 현황 평가를 수행하였다. 연구 결과 는 서울시 유아숲체험장의 질적 수준 향상에 기초 자료로서 활 용될 수 있다. 


\section{II. 이론 고찰}

\section{1. 유아와 숲체험}

만 3 5세를 의미하는 유아기는 유아의 전인적 성장에 매우 중요한 시기이다. 만 3 세부터 형성되는 유아의 지적 능력은 외 부 자극을 수용하고 반응하면서 발달된다 $(\mathrm{Kim}, 2010)$. 숲은 이 러한 감각 능력을 개발할 수 있는 최적의 장소이다(Kim, 2010). 체험의 사전적 의미는 "자기가 몸소 겪음. 또는 그런 경험"으로 일반적으로 체험은 대상과의 직접적인 접촉을 의미한다 $(\mathrm{Kim}$, 2003; https://stdict.korean.go.kr/). 따라서 유아의 숲체험이란 숲에서 접할 수 있는 다양한 자연 요소를 온몸으로 느끼며 직접 적이고 감각적으로 경험하는 모든 활동을 의미한다(Lee, 2012).

8 세부터 13세까지의 연령층은 이러한 체험학습만으로 만족 하지 않고 여러 자연 현상의 연관관계를 이해하는데 더 큰 관 심을 보이나, 8세 미만의 유아는 숲에서의 체험적인 활동만으 로 학습효과가 충분하다 $(\mathrm{Kim}, 2010)$. 유아의 숲체험은 놀이와 체험만으로 효과를 기대할 수 있으며, 직접적인 지식 전달이 아 닌 놀이를 통한 간접적인 배움이 이뤄져야 한다. 유아의 놀이는 장소의 구애를 받지 않으나 모든 유아가 처음부터 솦체험에 흥 미를 느끼고 적응하는 것은 아니므로 유아가 숲을 충분히 탐색 할 수 있는 프로그램 계획이 필요하다(Lim and Kwak, 2015).

\section{2. 유아수체험장 공간 구성}

선행연구 검토를 통해 서울시 유아숲체험장 현장조사연구를 수행하기 위한 평가 항목을 도출하였다. 첫째, 숲체험 효과를 높이는 유아숲체험장의 위치적 특징과 공간 요소를 살펴보고 공통된 공간 요소를 평가 항목으로 선정하였다. 둘째, 실외놀이 공간의 구성을 살펴보고 이를 유아숲체험장 야외체험학습장을 분류하고 다양성을 평가하는 기준으로 사용하였다.

\section{1) 위치와 공간 요소}

Lee(2003)는 독일의 숲유치원 설립 시 고려되는 숲의 요건 을 소개하였다. 독일의 숲유치원은 일반 유치원에 준하는 정식 유아교육기관으로 주로 건물이 없는 완전한 숲에서 교육이 행 해지는 순수한 자연형태의 숲유치원으로 운영된다(Lee, 2003). 자연친화적 유아교육의 모델로 불리는 독일의 숲유치원은 국 내 유아숲체험장이 지향하는 바와 같다. 독일의 숲유치원은 유 아의 등 - 하원을 고려하여 숲이 있는 지역까지의 교통 접근성 을 고려한다. 숲은 시야 확보를 위해 수목의 밀도가 낮은 것이 좋고, 장소와 계절에 따라 만나게 되는 숲의 모습이 다양할수 록 좋다. 또한 온전한 유아만의 숲체험 공간이 될 수 있도록 주 산책 동선은 피한다.
Kwon(2012)은 참여관찰을 통해 유아의 다양한 체험을 돕는 유아숲체험장 설계 요소를 도출했다. 오를 수 있는 지형, 올라 탈 수 있는 나무 - 통나무 - 바위, 나무 - 울타리 또는 산책로가 둘러싸고 있는 구역, 깊지 않은 솦, 소리를 만들 수 있는 요소, 팔 수 있는 땅과 모래, 숨을 수 있는 아지트, 물놀이 공간, 동선, 휴식을 위한 그루터기, 공터, 대피소 및 재료 보관 창고, $1 \sim 2 \mathrm{~km}$ 의 산책로와 10명 이상이 모일 수 있는 평지 등을 설계 요소로 제시하였다. 체험장의 위치는 숲의 입구까지 차량 접근 이 가능하고 큰 길에서 멀리 떨어지지 않은 곳이 좋다. 개별 요 소뿐만 아니라 대상지가 가지고 있는 특징적인 요소들을 찾아 내 유아의 흥미와 탐구를 자극하도록 유도하는 것이 중요하다.

Korea Forest Service(2014)는 유아숲체험원 조성시 고려사 항을 제시하였다. 공간적 특징으로 유아 30 명이 활동할 수 있 는 평탄지를 2 곳 이상 확보 가능한 곳, 차량 접근이 용이한 곳, 초본 - 관목이 풍부한 곳, 자연재해 또는 위험지형 등 위험요소 가 없는 곳을 권고하였다.

Kang(2015)은 참여관찰을 통해 상징-집단 놀이의 발현에 영향을 주는 물리적 환경을 탐구하고 설계 지침을 도출하였다. 상징-집단놀이는 유아의 자유놀이 중 가장 높은 수준의 정서적 발달을 보여주는 놀이 유형으로 유아 발달에 중요한 의미를 갖 는다(Kang, 2015). 연구 결과 교목 밀도가 빈 공간일 때, 경사 가 10 20도 일 때, 자연 낱개 재료가 대형으로 땅에 고정된 경 우, 대형 그루터기를 이용한 활동인 경우, 포장 재료가 흙인 경 우 상징-집단 놀이의 발현 횟수가 높았다. 이를 바탕으로 생물 다양성, 접근성, 안전성, 경사 다양성, 숲길로의 연결성, 숲속 공간의 필수적 마련, 교목의 밀도가 낮은 공간, 10 20도의 경 사지, 고정된 대형 그루터기 활용, 자연 낱개 재료의 확보, 포장 재료는 흙과 모래 사용을 설계요소로 제시하였다.

선행연구 검토 결과, 유아숲체험장은 숲의 입구까지 차량 접 근이 편리해야 한다. 또한 수목의 밀도가 낮아 시야의 확보가 가능하고 유아의 자유로운 놀이가 가능한 숲이 좋다. 높은 구 릉, 넓은 초원과 같이 유아가 다양한 지형을 몸으로 체험할 수 있는 곳이 좋고 계곡, 얕은 물가, 생태 연못, 나무 군락 등 탐구 할 수 있는 자연환경이 다양할수록 좋다. 숲체험에 참여한 유 아가 전부 모일 수 있는 평탄지를 확보하고, 유아가 걷기에 적 당한 $1 \sim 2 \mathrm{~km}$ 정도의 숲길 또는 산책로를 마련하되 온전한 유 아만의 공간이 될 수 있도록 일반인의 주 이용 동선은 되도록 피하는 것이 좋다. 유아가 놀잇감으로 활용할 수 있는 자연 재 료가 풍부하게 제공되어야 하며 고정된 그루터기와 같은 고정 시설은 유아의 창의적인 놀이에 도움이 된다. 「산림교육법 시 행령」 별표3 유아숲체험원 등록기준에 따라 모든 유아숲체험 원은 차량의 접근이 가능한 $1 \mathrm{~km}$ 이내에 위치하므로 차량 접근 성에 대한 평가는 제외하고, 시야 확보(securing the view), 평 지 확보(flat land), 경사다양성(slope diversity), 식생다양성 
(vegetation diversity), 계곡 및 생태연못 등(valley or ecological pond etc.), 숲 산책길(forest trails), 자연놀이재료(ingredients for natural play) 총 7개 요소를 현장조사연구의 평가 항목으로 사용하였다(Table 1 참조).

\section{2) 실외놀이공간의 구성과 야외체험학습장}

(1) 실외놀이공간의 구성

일반적으로 유아교육기관에서는 유아 놀이 활동의 내용과 특징에 따라 구분된 놀이 영역으로 실내·외 공간을 구성한다 (Lee et al., 2001; Moon, 2003). 영역에 맞게 구성된 놀이 공간 은 유아의 전인적 성장을 촉진시킨다(Ministry of Education, 2013). 이때 각 영역이 분리되거나 한정되는 것이 아니라 상호 보완적인 관계를 이룰 수 있도록 각 영역 간의 균형을 유지하 는 것이 중요하다(Moon, 2003).

유아숲체험장은 하나의 실외놀이공간으로 실외놀이공간의 구성은 학자마다 분류와 명칭에 조금씩 차이가 있다. Ministry of Education(2013)은 운동놀이 영역, 모래 · 물놀이 영역, 자연 탐구 및 관찰 영역, 작업 영역, 휴식 영역, 보관창고로 구분하였 고, Jang(2015)은 선행연구를 통해 운동놀이 영역, 물· 모래놀 이영역, 목공놀이 영역, 동 - 식물 기르기 영역, 조용한 놀이 영 역, 개방된 영역으로 구분하였다. Choi and Byun(2006)과 Choi et al.(2010)는 선행연구를 통해 신체놀이 영역, 비구조화 및 극
화놀이 영역, 휴식 영역, 자연탐구 영역, 모험놀이 영역으로 구 분하였는데 이 중 비구조화 및 극화놀이 영역에는 물·모래 영 역, 전이 영역, 목공놀이 영역, 창고 등이 포함된다.

선행연구를 바탕으로 본 연구에서는 활동의 성격에 따라 운 동놀이 영역(exercise play area), 물·모래놀이 영역(water and sand play area), 목공놀이 영역(woodworking play area), 자연탐구 영역(nature exploration area), 조용한 영역(calm area), 개방된 영역(open area)으로 구분하였다(Table 2 참조). Jang (2015)의 연구를 참고하여 실외놀이공간을 구성하는 영 역별 특징을 정리하고 이를 유아숲체험장에 대입하였다.

운동놀이 영역은 오르기, 달리기, 매달리기 등 대근육을 활 용한 운동놀이가 이뤄지는 영역으로 조합놀이대, 그네, 미끄럼 틀 등의 놀이 기구를 예로 들 수 있다. 유아는 운동놀이를 함으 로서 몸을 조정하고 움직이는 과정을 경험하며 신체 능력을 발 달시킨다. 유아숲체험장의 조합놀이대와 경사 오르기, 나무 타 기, 밧줄 건너기, 통나무 건너기 등 신체 발달을 위한 공간과 낙엽 놀이, 맨발로 걷기, 소리 듣기, 바람 느끼기 등 감각 발달 을 위한 공간이 운동놀이 영역에 속한다.

물·모래놀이 영역은 물과 모래를 이용한 놀이가 이뤄지는 공간으로(Lee, 2000), 유아는 물, 모래, 흙, 나뭇가지, 돌멩이 등 의 자연물을 이용한 놀이로 스트레스를 해소한다. 이 영역은 도구를 활용한 구성 놀이기가 빈번히 일어나는 영역이기도 하 다. 유아의 다양한 놀이 행태를 유도하기 위하여 충분한 놀이

Table 1. Literature reviews for spatial elements

\begin{tabular}{|c|c|c|}
\hline Classification & Spatial elements & Evaluation elements \\
\hline Lee(2003) & $\begin{array}{l}\text { Vehicle accessibility, low tree density to secure the view, the diversity of forests according to } \\
\text { location and season, own space for preschoolers }\end{array}$ & \multirow{4}{*}{$\begin{array}{l}\text { 1. Securing the view } \\
\text { 2. Flat land } \\
\text { 3. Slope diversity } \\
\text { 4. Vegetation diversity } \\
\text { 5. Valley or ecological pond etc. } \\
\text { 6. Forest trails } \\
\text { 7. Ingredients for natural play }\end{array}$} \\
\hline Kwon(2012) & $\begin{array}{l}\text { Topography where preschoolers can climb up, trees } \cdot \text { logs and rocks where preschoolers can climb } \\
\text { up, surrounded space, a nearby forest, elements that can make sounds, ground and sand, a } \\
\text { hideout, water play area, own space for preschoolers, resting stump, vacant land, shelter and } \\
\text { material storage warehouse, vehicle accessibility, forest trail( } 1 \text { to } 2 \mathrm{~km}) \text {, flat land(more than } 10 \\
\text { people) }\end{array}$ & \\
\hline $\begin{array}{l}\text { Korea Forest } \\
\text { Service(2014) }\end{array}$ & $\begin{array}{l}\text { Flat land(more than } 30 \text { people, more than } 2 \text { places), vehicle accessibility, vegetation diversity, a } \\
\text { place where there's no dangerous factors }\end{array}$ & \\
\hline Kang(2015) & $\begin{array}{l}\text { Biodiversity, accessibility, safety, slope diversity, connection with forest trails, space in the forest, } \\
\text { low tree density to secure the view, a fixed stump, ingredients for natural play, soil and sand }\end{array}$ & \\
\hline
\end{tabular}

Table 2. Literature reviews for composition of outdoor play area

\begin{tabular}{|c|c|c|}
\hline Classification & Composition of outdoor play area & Evaluation elements \\
\hline $\begin{array}{c}\text { Ministry of } \\
\text { Education(2013) }\end{array}$ & $\begin{array}{l}\text { Exercise play area, water and sand play area, nature exploration and observation area, working } \\
\text { area, rest area, storage warehouse }\end{array}$ & \multirow{4}{*}{$\begin{array}{l}\text { 1. Exercise play area } \\
\text { 2. Water and sand play area } \\
\text { 3. Woodworking play area } \\
\text { 4. Nature exploration area } \\
\text { 5. Calm area } \\
\text { 6. Open area }\end{array}$} \\
\hline Jang(2015) & $\begin{array}{l}\text { Exercise play area, water and sand play area, woodworking play area, animal and plant area, } \\
\text { calm area, open area }\end{array}$ & \\
\hline $\begin{array}{l}\text { Choi and } \\
\operatorname{Byun}(2006)\end{array}$ & \multirow{2}{*}{$\begin{array}{l}\text { Exercise play area, unstructured and acting play area(water and sand area, transfer area, } \\
\text { woodworking play area, warehouse etc.), rest area, nature exploration area, adventure play area }\end{array}$} & \\
\hline Choi et al.(2010) & & \\
\hline
\end{tabular}


공간과 자연 재료가 제공되어야 한다.

목공놀이 영역은 나무, 망치, 못 등의 도구를 사용하여 간단 한 구성물을 만들어보는 영역이다. 목공놀이 영역은 교구 위주 로 사용되기 때문에 고정적으로 운영되기보다는 유아의 흥미 나 활동 주제에 따라 일시적으로 설치 및 운영될 수 있다(Jin, 2005). 유아들은 목공놀이를 통하여 나무의 무게, 질감, 부피, 길이, 넓이 등을 눈과 손으로 느끼고 물체를 만들어봄으로써 상상력을 펼치며 성취감을 느낄 수 있다.

자연탐구 영역에서는 유아가 동물과 식물을 기르며 관찰 조 사 실험 등의 탐구를 한다(Choi and Byun, 2006; Jang, 2015). 장기간 동안 자연물의 변화를 지켜봄으로써 자연을 이해하고 정서적 교감을 나누는 것이 이 영역의 핵심이다. 연구자는 유 아가 숲체험을 통해 지속적으로 숲에 방문하고 탐구하면서 자 연을 배워간다는 점에서 유아숲체험장 전체를 자연탐구 영역 으로 보았다.

조용한 영역은 실내 놀이 활동을 실외로 연장한다. 유아는 조용한 놀이 영역에서 휴식을 취하거나 책 읽기, 그림 그리기, 음악 감상 등의 정적인 활동을 즐긴다. 신체적 발달은 운동 놀 이를 통한 근육의 사용뿐만 아니라 적절한 긴장 완화와 휴식을 취해야만 정상적으로 이루어질 수 있다는 점에서 실외놀이 공 간에도 조용한 놀이 영역의 조성이 필요하다(Kim, 1997).

개방된 영역은 고정된 놀이시설물 없이 잔디밭, 빈 마당 등 과 같이 개방된 넓은 공간을 말한다. 개방된 영역에서는 공, 줄, 끈 등 소품으로 많은 놀이를 할 수 있다.

$\operatorname{Kang}$ (2019)은 유아참여설계를 통해 유아가 선호하는 유아 숲체험원 설계안을 도출하였다. 유아가 그린 설계안을 분석한 결과 전체, 성별, 나이별 모두 신체 및 모험놀이공간을 가장 많 이 그렸다. Kang(2019)은 선행연구를 바탕으로 신체 및 모험 놀이공간에 대한 유아의 선호는 유아발달 시기에 따라 요구되 는 놀이공간임을 분석하였다. 그러나 유아가 가장 선호하는 설 계안은 동적놀이공간형이 아닌 자연공간형이었는데, 이를 유아 가 전체적인 시각에서 인지발달 유형별 공간이 고루 배치된 설 계안을 선택한 것으로 해석했다. 자연공간형은 놀이시설공간과 물놀이 공간, 흙놀이 공간이 적절한 양적 배치를 이루고 있어 유아의 전인적 성장을 위한 인지적 발달놀이(기능놀이, 구조놀 이, 상징놀이) 전 영역이 충분히 발현될 수 있다고 보았다.

유아교육에서 놀이는 유아의 전인적 성장을 돕는 가장 적절 한 교육 방법으로 알려져 있다(Moon, 2003). 따라서 유아의 흥 미를 불러일으킬 수 있는 놀이 환경을 제공하는 것 역시 매우 중요하다(Moon, 2003). 유아 선호도가 높은 공간에서 유아는 자연스럽게 놀이를 시작할 수 있다. 숲체험을 통한 유아의 전 인적 성장이 충분히 발현될 수 있도록 유아 선호도가 높고 발 달에 요구되는 신체놀이공간을 충분히 제공하고 영역별 균형 을 고려하여 물놀이, 흙놀이와 같은 자연 재료를 이용한 체험
공간을 함께 배치해야 한다.

(2) 야외체험학습장

야외체험학습장 ${ }^{4)}$ 이란「산림교육법 시행령」에 따라 유아숲 체험장이 갖추어야 하는 시설 중 하나로 숲체험, 생태놀이, 관 찰학습 등을 할 수 있는 공간을 의미한다. 산림청 매뉴얼에 따 르면 야외체험학습장은 유아들이 활동할 수 있는 공간의 개념 으로 반드시 인위적인 시설물이 있는 면적만을 의미하지 않으 며 활동 공간으로 구획된 면적을 의미한다. 야외체험학습장은 유아숲체험원을 구성하는 주요 활동 공간으로 산림청은 다양 한 프로그램이 운영될 수 있도록 대상지 세부 공간별 특성을 반영할 것을 권고하였다. 산림청은 매뉴얼에서 물놀이 공간, 흙 놀이 공간, 밧줄을 활용한 공간, 모임공간, 균형시설, 자연소리 를 듣는 공간, 맨발체험장, 야생화단지 등을 예로 들었다.

야외체험학습장은 유아숲체험장을 구성하는 주요 활동 공간 이다. 유아숲체험장의 구성을 살펴보기 위하여 야외체험학습장 이 영역별로 골고루 조성되었는지 평가하였다.

\section{3. 유아숲체험장 이용 경험}

유아숲체험장을 정기적으로 방문하고 솦체험 프로그램을 진 행해 온 이용 주체의 경험은 유아숲체험장 현황 파악에 매우 중요하다. 유아교육기관 교사 심층면담을 진행한 $\operatorname{Ham}(2016)$ 과 $\operatorname{Han}(2020)$ 의 연구와 유아숲지도사 심층면담을 진행한 $\mathrm{Heo}$ (2016)와 Lee(2017)의 연구를 통해 이용 주체의 경험과 인 식을 정리하였다.

\section{1) 공간}

유아교육기관 교사는 유아가 숲체험을 통해 자연을 느끼기 를 기대했다. $\operatorname{Ham}(2016)$ 의 면담 대상자들은 현재 이용하고 있 는 체험장이 자연 공간이 부족하며 인위적인 놀이시설과 지나 친 안전시설로 인해 숲체험의 본래 취지를 잃은 것 같다고 하 였다. 자연 공간에서는 놀이 시설물을 이용할 때보다 정적인 놀이가 많이 이뤄지기 때문에 안전상의 위험이 덜하다고 이야 기하며 자연 공간이 더 늘어나기를 바랐다. $\operatorname{Han}(2020)$ 의 면담 대상자 중 $\mathrm{A}$ 교사는 유아숲체험장이 매우 정돈되어 있어 유아 의 효과적인 숲체험이 어렵다고 하였다. 위험요소가 없고 잘 가꿔진 공간에서는 아이들이 몸으로 체험하면서 자기 조절 능 력을 키우기 어렵기 때문에 깨끗하게 정리된 공원이 아닌 숲이 필요하다고 하였다. 이와 반대로 $\mathrm{B}, \mathrm{C}$ 교사는 유아숲체험장 내 놀이 시설물과 교구가 체계적으로 조성되어 있어 좋았다고 답 변했다.

$\mathrm{Heo}$ (2016) 와 Lee(2017)는 유아숲지도사 심층면담을 진행하 였다. 유아숲지도사 역시 유아교육기관 교사와 같이 생태 지식 
의 전달보다 유아 스스로 숲을 체험하고 느끼기를 원했다. 두 연구에서 유아숲지도사의 유아숲체험장 내 놀이 시설물에 대 한 인식은 다뤄지지 않았으나 자연물로 만들어진 시설물은 관 리가 되지 않아 안전상의 문제가 있으며, 유아가 숲체험 활동 을 하기에 다소 좁아 넓은 평지가 필요하다는 의견이 있었다. 시설물의 경우 못이 빠지거나 밧줄이 풀어지는 경우, 비에 젖 은 나무가 썩어 부러지는 경우, 놀이 교구가 썩고 벌레가 생기 는 등의 안전 문제가 있고 유아가 목재 시설물과 교구를 좋아 하기 때문에 구청의 체계적인 관리가 반드시 필요하다고 하였 다. 모래 놀이터의 관리가 소홀한 경우 동물의 배설물이나 유 리조각이 발견되어 상당히 위험하다.

\section{2) 체험 프로그램}

유아교육기관 교사와 유아숲지도사 모두 지속적인 숲체험이 중요하다고 하였다. $\mathrm{Heo}$ (2016)의 유아숲지도사들은 3개월에 한 번씩 숲에 오는 아이들은 숲에 와도 무엇을 해야 할지 모르 고 이전 숲 활동과의 연계가 이뤄지지 않아 교육적 효과를 기 대하기 어렵다고 하였다. 숲이 낮선 아이들은 스스로 안전에 대한 생각이 없어 다치는 경우가 많다고 한다.

수업 진행 시 유아숲지도사 1 명 당 적정 유아 수는 지도사와 교사 모두 약 7 명이 적당하다고 하였다. 이용자 만족도 분석을 실시한 Lee(2014)도 프로그램 진행 시 유아숲지도사 1명당 7 10명을 수용하는 것이 가장 적당하다는 결과를 도출했다. Lee(2017)의 연구에서 $\mathrm{D}$ 유아숲지도사는 지도 인원이 부족할 경우 안전 관리가 어려워 지도사로서의 역량을 충분히 발휘하 지 못해 아쉽다고 하였다. 동행한 유아교육기관 교사가 반드시 수업에 함께 참여해야 숲 활동이 원활하게 진행될 것으로 보인 다. 유아교육기관 교사의 참여 태도와 역량도 유아 숲체험에 있어 매우 중요한 부분인데 $\operatorname{Ham}(2016)$ 의 면담 대상자 중 $\mathrm{E}$ 교 사는 숲체험장을 이용하기 전 사전 안내 교육이 있었으나 숲체 험을 처음 시작하는 교사에게 실질적인 도움이 되지 않아 의미 가 없었다고 한다.

\section{III. 연구의 방법과 대상}

본 연구는 이론 고찰, 현장조사연구, 전문가 인터뷰를 수행 하였다. 이론 고찰을 통해 유아와 숲체험의 개념과 숲체험 효 과를 높이는 공간 구성, 이용 주체의 경험을 정리하였고, 이를 바탕으로 서울시 유아숲체험장의 현황을 평가하기 위한 분석 표를 작성하였다.

현장조사연구 대상은 서울시 유아숲체험장 24곳으로 2019년 기준 유아숲체험장을 운영하지 않는 중구를 제외하고 자치구 별 한 곳씩 선정하였다. 서울시 유아숲체험장의 평균적인 물리 적 현황을 파악하기 위하여 관리기관이 다른 24 곳을 방문하였

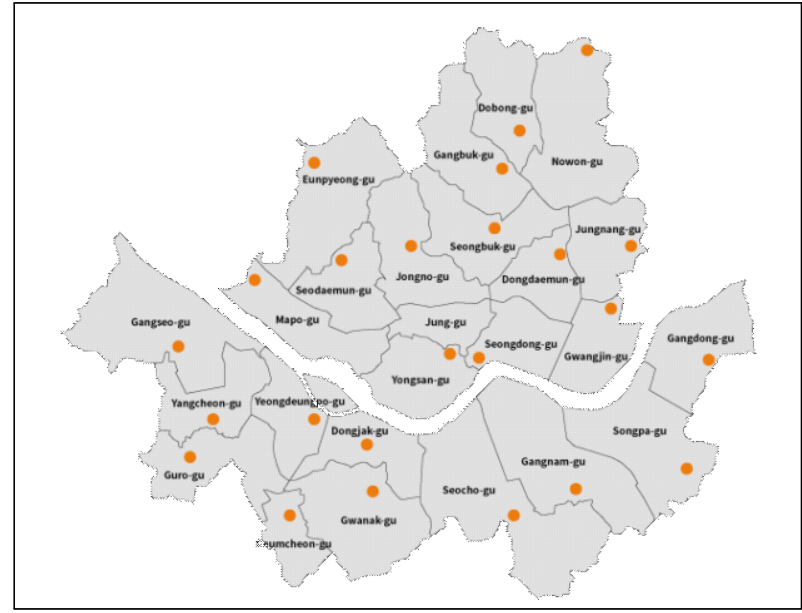

Figure 1. Location of field survey

다(Figure 1, Table 3 참조).

현장조사연구를 통한 분석 내용은 크게 두 가지로 나뉜다. 첫째, 유아숲체험장과 주변 환경을 살펴보았다. 유아의 숲체험

Table 3. List of field survey

\begin{tabular}{|c|c|c|c|}
\hline & $\begin{array}{c}\text { Management } \\
\text { agency }\end{array}$ & Name & $\begin{array}{l}\text { Area } \\
\left(\mathrm{m}^{2}\right)\end{array}$ \\
\hline 1 & Gangnam-gu & $\begin{array}{c}\text { Daemosan Forest Visitor Centers } \\
\text { for Little Children }\end{array}$ & 10,000 \\
\hline 2 & Gangdong-gu & Jongdalsae Forest " & 13,000 \\
\hline 3 & Gangbuk-gu & Odong Neighborhood Park Forest " & 8,000 \\
\hline 4 & Gangseo-gu & Kwonggogae Neighborhood Park Forest " & 8,600 \\
\hline 5 & Gwanak-gu & Cheongnyongsan Forest " & 9,700 \\
\hline 6 & Gwangjin-gu & Achasan Forest " & 10,000 \\
\hline 7 & Guro-gu & Jatjeol Park Forest " & 10,000 \\
\hline 8 & Geumcheon-gu & Bejjangi Forest " & 12,000 \\
\hline 9 & Nowon-gu & Suraksan Forest " & 13,000 \\
\hline 10 & Dobong-gu & Banditbuli Forest " & 10,000 \\
\hline 11 & Dongdaemun-gu & Baebongsan Park Forest " & 10,000 \\
\hline 12 & Dongjak-gu & Seodalsan Forest " & 13,000 \\
\hline 13 & Mapo-gu & Sangam Park Forest " & 15,000 \\
\hline 14 & Seodaemun-gu & Baegunsan Maebawi Forest " & 10,000 \\
\hline 15 & Seocho-gu & Munhwayesul Park Forest " & 14,000 \\
\hline 16 & Seongdong-gu & Daehyeonsan Forest " & 10,000 \\
\hline 17 & Seongbuk-gu & Gaeunsan Neighborhood Park Forest " & 9,000 \\
\hline 18 & Songpa-gu & Songpa Forest " & 8,000 \\
\hline 19 & Yangcheon-gu & Sinjeongsan Urungbawi Forest " & 10,000 \\
\hline 20 & Yeongdeungpo-gu & Yeongdeungpo Park Forest " & 6,000 \\
\hline 21 & Yongsan-gu & Eungbong Park Forest " & 10,100 \\
\hline 22 & Eunpyeong-gu & Seooreung Forest " & 10,000 \\
\hline 23 & Jongno-gu & Samcheong Park Forest " & 13,000 \\
\hline 24 & Jungnang-gu & Yongmasan Forest " & 10,000 \\
\hline
\end{tabular}


이 이뤄지는 다양한 자연 요소(지형, 식생, 수공간 등)와 유아 가 놀이에 활용할 수 있는 풍부한 자연 재료(흙, 나뭇잎, 열매 등)의 유무, 체험장의 위치와 구조에 따른 특징 등을 조사했다. 이론 고찰을 통해 숲체험 효과를 높이는 공간 요소 7가지를 도 출하였고 Table 4 의 항목을 기준으로 대상지 24곳의 현황을 평 가하였다. 7 가지 공간 요소는 시야 확보, 평지, 경사 다양성, 식 생 다양성, 계곡 또는 생태연못 등 수공간, 숲길, 자연놀이재료 이며 평가는 뛰어남, 좋음, 나쁨, 없음 4 가지로 구분하였다.

둘째, 야외체험학습장의 종류와 배치를 살펴보았다. 야외체 험학습장이 실외놀이공간 구성 영역에 따라 골고루 조성되어 있는지 확인하고 시설물의 배치에 따른 특징을 살펴보았다. 야 외체험학습장 중 신체 능력과 감각 능력 발달을 위한 영역은 운동놀이 영역으로, 물과 모래가 활동의 주재료가 되는 영역과 수공간은 물·모래놀이 영역으로 분류하였다. 교구와 도구를 활용하여 창작 활동을 하는 영역은 목공놀이 영역, 휴식과 정 적 활동이 벌어지는 영역은 조용한 영역, 고정된 시설물 없이 자유롭게 뛰놀며 소품을 활용한 신체 활동이 가능한 넓은 영역 은 개방된 영역으로 분류하였다.

전문가 인터뷰는 서울시 유아숲체험장 이용 경험이 있는 유 아교육기관 교사 2인, 유아숲지도사 3 인과 진행하였다(Table 5
참조). 전문가 인터뷰의 목적은 유아교육학 전문가의 관점에서 서울시 유아숲체험장의 물리적 현황을 살펴보고 숲체험에 대 한 인식과 이용 경험을 공유하기 위함이다. 이론 고찰을 통해 정리한 이용 경험과 전문가 인터뷰 결과를 반영하여 현장조사 연구 결과를 해석하고 개선 방안을 도출하였다.

\section{IV. 연구 결과}

\section{1. 유아숲체험장 공간 구성}

\section{1) 유아숲체험장 및 주변 환경}

첫째, 서울시 유아숲체험장은 위치적 특성과 공간 구조에 따 라 6 가지 유형으로 분류되며, 각 유형별 특징을 갖는다. 본 연 구는 Kang(2015)의 연구와 연구자의 현장조사연구를 통해 서 울시 유아숲체험장의 유형을 분류하였다 ${ }^{5}$. 먼저 위치적 특성에 따라 유아숲체험장이 평지형 근린공원 내 조성된 경우 평지형 으로, 산지형 근린공원 내 조성된 경우 산지형으로 분류하였고 두 가지 특징을 모두 갖는 경우 혼합형으로 분류하였다. 그리 고 공간 구조와 야외체험학습장의 배치에 따라 응집형과 분산

Table 4. Method of field survey

\begin{tabular}{|c|c|c|c|c|c|}
\hline & & (O) (Outstanding) & $O($ Good $)$ & $\triangle(\mathrm{Bad})$ & $\times$ (None) \\
\hline 1 & Securing the view & - A wide and open view & $\begin{array}{l}\text { - Located in a } \\
\text { medium-density forest }\end{array}$ & $\begin{array}{l}\text { - Visibility is not secured due } \\
\text { to tree density and } \\
\text { topography }\end{array}$ & $\begin{array}{l}\text { - Not safe because it's dense } \\
\text { and completely surrounded } \\
\text { by trees }\end{array}$ \\
\hline 2 & Flat land & $\begin{array}{l}\text { - There is a large flat land } \\
\text { where more than } 10 \\
\text { children can gather }\end{array}$ & $\begin{array}{l}\text { - There is a flat land where } \\
\text { less than } 10 \text { children can } \\
\text { gather }\end{array}$ & $\begin{array}{l}\text { - There is flat land, but } \\
\text { facilities are installed }\end{array}$ & - There is no flat land \\
\hline 3 & Slope diversity & $\begin{array}{l}\text { - There are a lot of } \\
\text { small-scale natural } \\
\text { topography where can do } \\
\text { physical activities }\end{array}$ & $\begin{array}{l}\text { - There is a small-scale } \\
\text { natural topography where } \\
\text { can do physical activities }\end{array}$ & $\begin{array}{l}\text { - There is a slope topography } \\
\text { that stairway type }\end{array}$ & - There is no slope \\
\hline 4 & Vegetation diversity & $\begin{array}{l}\text { - There are various species of } \\
\text { trees, shrubs, and flowers } \\
\text { that can be observed }\end{array}$ & - Planted mainly tall trees & $\begin{array}{l}\text { - Few species can be } \\
\text { observed }\end{array}$ & - There is no vegetation \\
\hline 5 & $\begin{array}{c}\text { Valley or ecological pond } \\
\text { etc. }\end{array}$ & $\begin{array}{l}\text { - There is a large water } \\
\text { space that children can } \\
\text { approach closely }\end{array}$ & $\begin{array}{l}\text { - There is a small water } \\
\text { space that children can } \\
\text { approach closely }\end{array}$ & $\begin{array}{l}\text { - There are water spaces } \\
\text { such as valleys and } \\
\text { ecological ponds, but there } \\
\text { is no water or access is } \\
\text { difficult }\end{array}$ & $\begin{array}{l}\text { - There is no water space } \\
\text { such as valleys or ecological } \\
\text { ponds }\end{array}$ \\
\hline 6 & Forest trails & $\begin{array}{l}\text { - Enough forest experience is } \\
\text { possible just by taking a } \\
\text { walk to forest trails }\end{array}$ & $\begin{array}{l}\text { - There is a forest trail } \\
\text { where can take a walk }\end{array}$ & $\begin{array}{l}\text { - There is a forest trail } \\
\text { where can take a walk, but } \\
\text { it's a part of the park and } \\
\text { tidy }\end{array}$ & $\begin{array}{l}\text { - There is no forest trail to } \\
\text { take a walk }\end{array}$ \\
\hline 7 & $\begin{array}{l}\text { Ingredients } \\
\text { for natural play }\end{array}$ & $\begin{array}{l}\text { - Various kinds of leaves, } \\
\text { fruits, soil, branches, and } \\
\text { flowers } \\
\text { - Not cleaned up the } \\
\text { ingredients for natural play }\end{array}$ & $\begin{array}{l}\text { - There is the ingredients for } \\
\text { natural play }\end{array}$ & $\begin{array}{l}\text { - There is a little quantity } \\
\text { and kinds of the } \\
\text { ingredients for natural play }\end{array}$ & $\begin{array}{l}\text { - There is no the ingredients } \\
\text { for natural play } \\
\text { - Very cleaned up the park }\end{array}$ \\
\hline
\end{tabular}


Table 5. Information about interviewees

\begin{tabular}{c|c|c|l}
\hline & Interviewees & Career & \multicolumn{1}{c}{ Reference } \\
\hline A & Director of a kindergarten & 29 years & $\begin{array}{l}\text { In 2006, Leading the study on the improvement of infants' language expression skills through natural } \\
\text { experiences } \\
\text { In 2008, obtained a master's degree in research on infant forests }\end{array}$ \\
\hline B & Kindergarten teacher & 18 years & $\begin{array}{l}\text { Participated in classes at the Seoul forest visitor centers for little children } \\
\text { Participation in the forest program run by kindergarten }\end{array}$ \\
\hline C & Forest guide for little children & 13 years & $\begin{array}{l}\text { In 2012, participated in monitoring infant observation at the Seoul infant forest experience center } \\
\text { In 2014, participated in writing out the manual of forest experience center by the Korea forest service }\end{array}$ \\
\hline D & Forest guide for little children & 8 years & Working as forest guide for little children in Seoul (Gwanak-gu) \\
\hline E & Forest guide for little children & 8 years & Working as forest guide for little children in Seoul(Gwangin-gu) \\
\hline
\end{tabular}

형으로 분류하였다. 야외체험학습장이 한정된 체험장 영역 내 에 배치되었을 경우 응집형으로, 공원 내 동선이나 등산로를 따라 배치되었을 경우 분산형으로 나누었다. 현장조사연구 대 상인 유아숲체험장 24곳은 평지-응집형, 산지-응집형, 산지-분
산형, 혼합-분산형 4 가지 유형에 속했다(Table 6 참조). Table 6 은 솦체험 효과를 높이는 7 가지 공간 요소에 대하여 Table 4 의 기준으로 평가한 결과로 다음과 같이 해석하였다.

평지형 근린공원에 조성된 유아숲체험장의 경우 활용할 수

Table 6. Results of field survey

\begin{tabular}{|c|c|c|c|c|c|c|c|c|c|c|c|c|c|c|c|}
\hline \multirow[t]{2}{*}{ Type } & \multirow{2}{*}{$\begin{array}{l}\text { Management } \\
\text { agency }\end{array}$} & \multicolumn{7}{|c|}{$\begin{array}{l}\text { Whithin the area designated } \\
\text { as the forest visitor centers for little children }\end{array}$} & \multicolumn{7}{|c|}{$\begin{array}{l}\text { Around the area designated } \\
\text { as the forest visitor centers for little children }\end{array}$} \\
\hline & & $\mathrm{a}$ & $\mathrm{b}$ & c & $\mathrm{d}$ & $\mathrm{e}$ & $\mathrm{f}$ & $\mathrm{g}$ & $\mathrm{a}$ & $\mathrm{b}$ & c & $\mathrm{d}$ & $\mathrm{e}$ & $\mathrm{f}$ & g \\
\hline \multirow{3}{*}{$\begin{array}{l}\text { Flatland- } \\
\text { cohesion type }\end{array}$} & Dobong-gu & 0 & (0) & $\triangle$ & 0 & $x$ & $x$ & 0 & 0 & 0 & $x$ & 0 & $x$ & $x$ & $x$ \\
\hline & Seocho-gu & () & (0) & $x$ & (0) & $x$ & $\triangle$ & (0) & () & () & $x$ & 0 & $x$ & $x$ & $x$ \\
\hline & Yeongdeungpo-gu & 0 & (a) & $x$ & $\triangle$ & $\triangle$ & $x$ & $\triangle$ & (0) & () & $x$ & $\Delta$ & $x$ & $x$ & $x$ \\
\hline \multirow{15}{*}{$\begin{array}{l}\text { Mountain- } \\
\text { cohesion type }\end{array}$} & Gangnam-gu & 0 & $\triangle$ & $\triangle$ & 0 & $x$ & $x$ & 0 & 0 & O & O & 0 & $x$ & () & 0 \\
\hline & Gangdong-gu & 0 & 0 & O & 0 & 0 & $\triangle$ & 0 & 0 & $x$ & o & o & $x$ & () & 0 \\
\hline & Gangseo-gu & 0 & O & $\triangle$ & O & $x$ & $x$ & 0 & 0 & $x$ & o & o & $x$ & () & 0 \\
\hline & Gwanak-gu & 0 & (a) & O & O & $x$ & 0 & 0 & O & o & O & o & (a) & () & 0 \\
\hline & Gwangjin-gu & 0 & $\triangle$ & O & 0 & $x$ & $x$ & $\triangle$ & 0 & O & O & 0 & () & () & $\triangle$ \\
\hline & Guro-gu & 0 & $\triangle$ & 0 & 0 & $x$ & 0 & (0) & 0 & 0 & 0 & 0 & $x$ & () & () \\
\hline & Nowon-gu & 0 & 0 & 0 & 0 & (0) & (0) & (0) & 0 & $\triangle$ & 0 & 0 & () & () & () \\
\hline & Dongdaemun-gu & 0 & 0 & O & 0 & $x$ & 0 & (0) & 0 & $x$ & O & 0 & $x$ & 0 & 0 \\
\hline & Dongjak-gu & 0 & 0 & O & (0) & $x$ & $\triangle$ & (0) & 0 & $\Delta$ & O & (0) & $x$ & () & (O) \\
\hline & Seodaemun-gu & 0 & 0 & () & (0) & $x$ & $\triangle$ & (0) & 0 & $\Delta$ & $\triangle$ & 0 & $x$ & 0 & O \\
\hline & Seongdong-gu & 0 & $\triangle$ & $\triangle$ & 0 & $x$ & $x$ & 0 & 0 & O & $\triangle$ & 0 & $x$ & $\triangle$ & $\triangle$ \\
\hline & Seongbuk-gu & 0 & $\triangle$ & $\triangle$ & 0 & $x$ & 0 & $\triangle$ & 0 & () & $\triangle$ & 0 & $x$ & $\triangle$ & $\triangle$ \\
\hline & Yangcheon-gu & 0 & 0 & O & (0) & $x$ & $x$ & (0) & 0 & $\Delta$ & $\triangle$ & 0 & O & 0 & $\triangle$ \\
\hline & Eunpyeong-gu & 0 & 0 & O & 0 & $x$ & $x$ & $\triangle$ & 0 & $\Delta$ & O & 0 & $x$ & () & $\triangle$ \\
\hline & Jungnang-gu & 0 & (0) & $\triangle$ & 0 & $x$ & (0) & 0 & 0 & $\triangle$ & 0 & 0 & $x$ & 0 & $\triangle$ \\
\hline \multirow{3}{*}{$\begin{array}{c}\text { Mountain- } \\
\text { distributed } \\
\text { type }\end{array}$} & Gangbuk-gu & 0 & 0 & O & (0) & $x$ & (0) & (0) & 0 & $\Delta$ & 0 & (0) & $x$ & () & (0) \\
\hline & Songpa-gu & 0 & 0 & O & 0 & $x$ & 0 & (0) & 0 & O & O & 0 & O & 0 & O \\
\hline & Yongsan-gu & $\triangle$ & 0 & o & 0 & $\triangle$ & (0) & (0) & 0 & $x$ & 0 & 0 & $x$ & () & (O) \\
\hline \multirow{3}{*}{$\begin{array}{c}\text { Mixed- } \\
\text { distributed } \\
\text { type }\end{array}$} & Geumcheon-gu & 0 & (0) & () & 0 & () & (0) & (0) & $\triangle$ & $x$ & () & (0) & () & () & (O) \\
\hline & Mapo-gu & 0 & 0 & O & (0) & (0) & (0) & 0 & 0 & 0 & O & (0) & $x$ & () & () \\
\hline & Jongno-gu & 0 & () & () & 0 & () & (1) & (1) & 0 & 0 & 0 & 0 & $x$ & 0 & $\Delta$ \\
\hline
\end{tabular}

Legend: a: Securing the view(시야확보), b: Flat land(평지), c: Slope diversity(경사다양성), d: Vegetation diversity(식생다양성),

e: Valley or ecological pond etc.(계곡 또는 생태연못 등), f: Forest trails(숲 산책길), g: Ingredients for natural play(자연놀이재료)

(O): Outstanding, $\mathrm{O}$ : Good, $\triangle$ : Bad, $\times$ : None. 
있는 자연 지형이나 재료가 충분하지 않아 숲체험에 매우 불리 하다. 일반 근린공원처럼 깨끗하게 관리되는 경우 자연물을 이 용한 놀이가 더욱 어려워지기 때문에 체험장 영역은 근린공원 과 다른 방식의 관리가 필요하다. 그러나 접근성이 매우 좋고 넓은 평지의 확보가 쉽기 때문에 안전사고의 부담이 적으므로 야생에 가까운 숲에서의 체험 이전에 숲, 흙, 모래와 같은 자연 물에 적응하기 위한 중간 단계의 체험장으로 활용 가능하다.

대다수의 유아숲체험장이 산지-응집형 유형에 속했으며 산 지형 근린공원의 자연환경을 그대로 이용할 수 있다는 점에서 숲체험에 가장 유리하다. 산지-응집형 유아숲체험장은 근린공 원 입구부에 조성된 경우와 등산로 또는 차량으로 접근할 수 있는 비교적 깊은 곳에 위치한 경우로 나뉜다. 깊은 숲에 위치 할수록 야생에 가까운 솦체험장 조성에 유리하나, 숲체험 환경 의 질적 수준 향상에 있어 기존 자연환경을 얼마나 활용하였는 가가 더 중요하다. 응집형 유아숲체험장은 지정된 체험장 영역 에 놀이 시설물이 모여 있기 때문에 시설의 비중이 높아 보이 나 유아숲체험장으로 지정되지 않은 구역의 자연 재료와 숲길, 수공간을 숲체험 공간으로 활용 가능하다.

산지-분산형 유아숲체험장의 경우 완만한 등산로를 따라 체 험 공간이 배치되어 있으며 산지형 근린공원의 이점으로 풍부 한 자연환경에서 숲체험이 진행된다. 숲길이 유아숲체험장으로 지정되어 있고 곳곳에 유아를 위한 체험 공간이 조성되어 있기 때문에 매번 다른 동선과 순서로 솦체험을 하며 유아의 지속적 인 흥미를 유발한다. 그러나 기존 등산로를 체험장 동선으로 사용하기 때문에 일반인의 휴식공간으로 사용되는 경우가 많 고, 평지를 확보하기 어렵다. 또한 체험 공간이 동선을 따라 하 나씩 배치되어 있어 유아의 집중력이 떨어질 수 있다. 숲체험 코스의 시작점이나 공원 내 시설을 활용하여 평지를 확보하고, 모임 공간과 개방된 영역의 마련이 필요하다.

혼합-분산형 유아숲체험장은 숲체험에 대한 부담이 적은 평 지형의 이점과 자연환경이 풍부한 산지형의 이점을 모두 가진 다. 따라서 숲체험이 어려운 영아나 만 3세 유아, 적극적인 신 체 활동을 하는 만 4 5세 유아가 같은 유아숲체험장, 다른 공 간에서 연령별 특성에 맞는 숲체험을 할 수 있다.

둘째, 서울시 유아숲체험장은 개별 체험장의 특징에 따라 숲 체험 효과가 달라질 수 있다. 예를 들어 평지-응집형 유아숲체 험장의 경우 접근성이 좋고 평지의 확보가 쉬우나 자연환경이 풍부하지 않다. 그러나 평지-응집형에 속하는 서초구 문화예술 공원 유아숲체험장은 목련, 메타세콰이어, 플라타너스와 같이 잎과 열매가 특징적인 수종이 밀도 높게 식재된 공간을 자연물 놀이 공간으로 활용함으로써 자연환경, 자연 재료가 풍부하지 않은 평지형 근린공원의 단점을 극복하고 숲체험의 효과를 높 였다. 서초구 문화예술공원과 영등포구 영등포공원은 도시 환 경에 둘러싸인 평지형 근린공원이라는 공통점이 있으나 서초
구 문화예술공원 유아숲체험장의 환경적 특징에 의해 더 높은 숲체험 효과를 기대할 수 있다.

산지형 유아숲체험장은 기존 자연환경을 숲체험에 활용할 수 있다는 점이 가장 큰 이점이다. 예를 들어 강남구 대모산 유 아숲체험장, 강북구 오동근린공원 유아숲체험장, 관악구 청룡 산 유아숲체험장, 동작구 서달산 유아숲체험장, 용산구 응봉공 원 유아숲체험장은 비교적 야생에 가까운 숲길과 완만한 등산 로를 가지고 있다. 등산로를 산행 코스로 계획하고 등산로와 물리적으로 연결된 유아숲ㅊㅎㅎㅁ장을 계획하여 숲체험 효과를 높일 수 있다. 광진구 아차산 유아숲체험장과 노원구 수락산 유아숲체험장은 체험장 주변 자연 계곡을 물놀이 공간으로 활 용해 유아가 보다 다양한 자연을 경험할 수 있다. 강북구 오동 근린공원 유아숲체험장은 자작나무 군락, 복자기 군락, 잣나무 군락 아래 체험 공간을 마련함으로써 수종별, 계절별로 다른 숲의 모습을 가까이서 관찰할 수 있도록 하였다. 각 산지형 근 린공원의 자연환경적 특징을 파악하고 이를 특화된 체험 공간 으로 구현함으로써 숲체험 효과를 높일 수 있다. 향후 유아숲 체험장 조성에 있어 대상지의 강점을 파악하고 이를 강조하는 것이 필요하며, 기존 사례를 참고하여 비슷한 조건을 가진 새 로운 대상지 발굴이 가능하다.

2) 야외체험학습장의 종류와 배치

첫째, 체험장 내 야외체험학습장의 경우 구성 영역을 기준으 로 고르게 구성된 체험장도 많았으나 전반적으로 운동놀이 영 역의 비중이 컸다(Table 7 참조). 예를 들어 강남구 대모산 유 아숲체험장과 노원구 수락산 유아숲체험장은 산지형 근린공원 중턱 경사지에 위치하며 주변 자연환경이 매우 풍부하다는 공 통점이 있다. 그러나 야외체험학습장의 영역별 구성을 비교했 을 때 노원구 수락산 유아숲체험장은 영역별로 고르게 구성되 어 있으나 강남구 대모산 유아숲체험장은 운동놀이 영역의 놀 이 시설물 위주로 구성되어 있다. 물리적 구성만으로 숲체험의 효과를 단정 지을 수는 없으나 놀이 시설물과 더불어 모래놀이 와 목공놀이를 할 수 있는 체험 공간과 교구, 물놀이를 할 수 있는 자연 계곡, 그림 그리기와 동화 읽기 등 정적인 활동이 가 능한 모임 공간과 숲속 교실을 마련함으로써 유아가 경험할 수 있는 숲체험의 범위는 넓어진다.

둘째, 야외체험학습장을 영역별로 분류하여 현황을 살펴본 결과, 영역별 시설물 유형을 구분할 수 있었다. 운동놀이 영역 의 시설물은 목재 조합 놀이대와 경사 오르기, 통나무 오르기, 통나무 건너기, 밧줄 놀이로 구분할 수 있었으며 감각 활동을 위한 낙엽 놀이, 맨발로 걷기, 바람 느껴보기를 할 수 있는 체 험 공간이 있었다. 운동놀이 영역은 신체활동을 위한 시설물로 구현되는 경우가 많았다.

모래놀이장 또한 다양한 형태로 조성되어 있었다. 모래만 있 
Table 7. Count result of outdoor experience learning zones

\begin{tabular}{|c|c|c|c|c|c|c|c|}
\hline Type & $\begin{array}{l}\text { Management } \\
\text { agency }\end{array}$ & a & $\mathrm{b}$ & c & d & $\mathrm{e}$ & Total \\
\hline \multirow{3}{*}{$\begin{array}{c}\text { Flatland- } \\
\text { cohesion } \\
\text { type }\end{array}$} & Dobong-gu & 6 & 2 & 1 & 3 & 2 & 14 \\
\hline & Seocho-gu & 1 & 2 & 2 & 1 & 2 & 8 \\
\hline & Yeongdeungpo-gu & 2 & 1 & - & 1 & 1 & 5 \\
\hline \multirow{15}{*}{$\begin{array}{c}\text { Mountain- } \\
\text { cohesion } \\
\text { type }\end{array}$} & Gangnam-gu & 8 & - & - & 1 & - & 9 \\
\hline & Gangdong-gu & 4 & - & - & 1 & 2 & 7 \\
\hline & Gangseo-gu & 9 & - & - & 3 & - & 12 \\
\hline & Gwanak-gu & 2 & 2 & 1 & 2 & 2 & 9 \\
\hline & Gwang.jin-gu & 3 & 1 & 2 & 3 & - & 9 \\
\hline & Guro-gu & 7 & 1 & 2 & 2 & - & 12 \\
\hline & Nowon-gu & 4 & 2 & 1 & 3 & 1 & 11 \\
\hline & Dongdaemun-gu & 6 & 2 & - & 2 & 2 & 12 \\
\hline & Dongjak-gu & 4 & - & 3 & 3 & 1 & 11 \\
\hline & Seodaemun-gu & 6 & - & 2 & 2 & 1 & 11 \\
\hline & Seongdong-gu & 3 & 2 & - & 2 & - & 7 \\
\hline & Seongbuk-gu & 3 & 1 & - & 2 & 2 & 8 \\
\hline & Yangcheon-gu & 7 & 1 & - & 1 & 2 & 11 \\
\hline & Eunpyeong-gu & 4 & 2 & - & 3 & - & 9 \\
\hline & Jungnang-gu & 4 & 1 & - & 2 & 1 & 8 \\
\hline \multirow{3}{*}{$\begin{array}{c}\text { Mountain- } \\
\text { distributed } \\
\text { type }\end{array}$} & Gangbuk-gu & 5 & 2 & 1 & 6 & 1 & 15 \\
\hline & Songpa-gu & 3 & 2 & 1 & 2 & 1 & 9 \\
\hline & Yongsan-gu & 2 & 1 & 2 & 2 & 1 & 8 \\
\hline \multirow{3}{*}{$\begin{array}{c}\text { Mixed- } \\
\text { distributed } \\
\text { type }\end{array}$} & Geumcheon-gu & 3 & 1 & - & - & 1 & 5 \\
\hline & Mapo-gu & 4 & 2 & 2 & 5 & 1 & 14 \\
\hline & Jongno-gu & 6 & 4 & 4 & 4 & 1 & 19 \\
\hline
\end{tabular}

Legend: a: Exercise play area, b: Water and sand play area, c: Woodworking play area, d: Calm area, e : Open area.

는 경우와 물놀이와 모래놀이를 함께할 수 있는 경우, 교구를 제공하는 경우, 통나무와 그루터기, 조합놀이대와 같은 고정 시 설물이 설치된 경우로 나뉘었다. 대다수의 유아숲체험장은 답 압이 심한 흙포장 또는 야자매트가 설치되어 있어 모래놀이는 모래놀이장에서만 가능했다.

수공간은 인공 시설과 자연 수공간으로 구분할 수 있었다. 모래놀이장 옆에 펌프를 설치한 경우 물·모래 놀이가 가능했 다. 생태 연못을 조성한 체험장도 많았는데 규모가 크지 않아 연못 가까이에서 동 - 식물 관찰 활동이 가능했다. 자연 계곡을 물놀이 공간으로 활용한 체험장은 노원구 수락산 유아숲체험장 과 종로구 삼청공원 유아숲체험장이었다. 광진구 아차산 유아
숲체험장 자연 계곡은 야외체험학습장으로 지정되지는 않았으 나 공원 입구에서 계곡으로 진입할 수 있어 물놀이가 가능했다.

목공놀이 영역은 목공놀이장을 따로 마련한 경우만 목공놀 이 영역으로 분류하였다. 평지 또는 그루터기나 통나무가 설치 된 경우, 테이블이나 평상이 설치된 경우로 나눌 수 있었다. 또 한 교구가 준비된 곳은 7곳이었으며 모두 나무 쌓기 놀이 교구 였다. 작은 크기의 교구부터 유아가 힘을 합쳐 옮겨야 하는 크 고 무거운 교구까지 다양했다.

조용한 영역은 정적인 활동이 가능한 공간과 휴식 공간을 포 함한다. 대부분이 휴식 공간으로 파고라, 평상, 의자와 넓은 테 이블이 많았다. 교사와 유아가 모여 앉아 구조적 프로그램을 진행할 수 있도록 그루터기나 의자를 설치하거나 스탠드 형식 의 숲속 교실을 조성한 곳도 많았다. 대다수의 유아숲체험장에 움집이 조성되어 있었는데 움집은 자연물을 이용한 상징놀이 ${ }^{6}$ 가 일어나는 공간이다.

개방된 영역은 고정 시설물이 없고 시야가 완전히 확보된 공 터이다. 산지형 근린공원의 경우 유아 10 30명이 활동할 수 있는 규모의 평지를 발굴하기 쉽지 않았다. 야생성이 높은 체 험장의 경우 공원 내 평지로 대체할 수 있고 소규모 평지를 여 러 곳 발굴하여 숲체험에 활용할 수 있다.

셋째, 야외체험학습장은 유아의 주요 활동 공간으로서 특정 숲체험 활동과 보다 적극적인 참여를 유도하기 위하여 시설물 로 구현될 수 있다. 유아숲체험장에 설치된 놀이 시설물은 단 순히 놀이터의 조합놀이대 기능을 넘어 숲체험을 돕는 도구, 매개체로 활용되어야 한다. Figure 2는 운동놀이 영역 중 목재 조합 놀이대, 경사 오르기, 통나무 오르기, 통나무 건너기와 목 공놀이 영역 중 교구가 준비된 경우, 조용한 영역 중 움집에 해 당하는 일부 야외체험학습장의 현황이다. 체험장 간의 구분이 어려울 정도로 시설물의 형태는 획일적이다. 그러나 유아숲체 험장은 위치적 특징과 공간 구성에 따라 숲체험의 폭이 달라진 다. 따라서 획일적인 시설물 위주로 조성된 현황을 숲체험 효 과를 낮추는 단편적인 요인으로 볼 수 없다. 예를 들어 움집의 물리적 형태보다 움집의 배치와 자연 재료 제공 여부가 유아의 상징놀이를 촉진시키고 전인적 성장을 돕기 때문이다. 개별 시 설물의 유무와 물리적 형태보다 시설물이 숲체험을 위한 매개 체로 기능하게 만드는 공간 구성이 더 다양한 활동을 유도하고 숲체험 효과를 높인다.

\section{2. 유아숲체험장 이용 경험}

서울시 유아숲체험장 이용 경험이 있는 유아교육기관 교사 2 인, 유아숲지도사 3 인을 대상으로 인터뷰를 진행하였다. 숲체 험에 대한 전문가 개인의 인식, 서울시 유아숲체험장의 물리적 공간, 운영 방식, 개선점에 대하여 묻고 답하며 유아교육학 전 


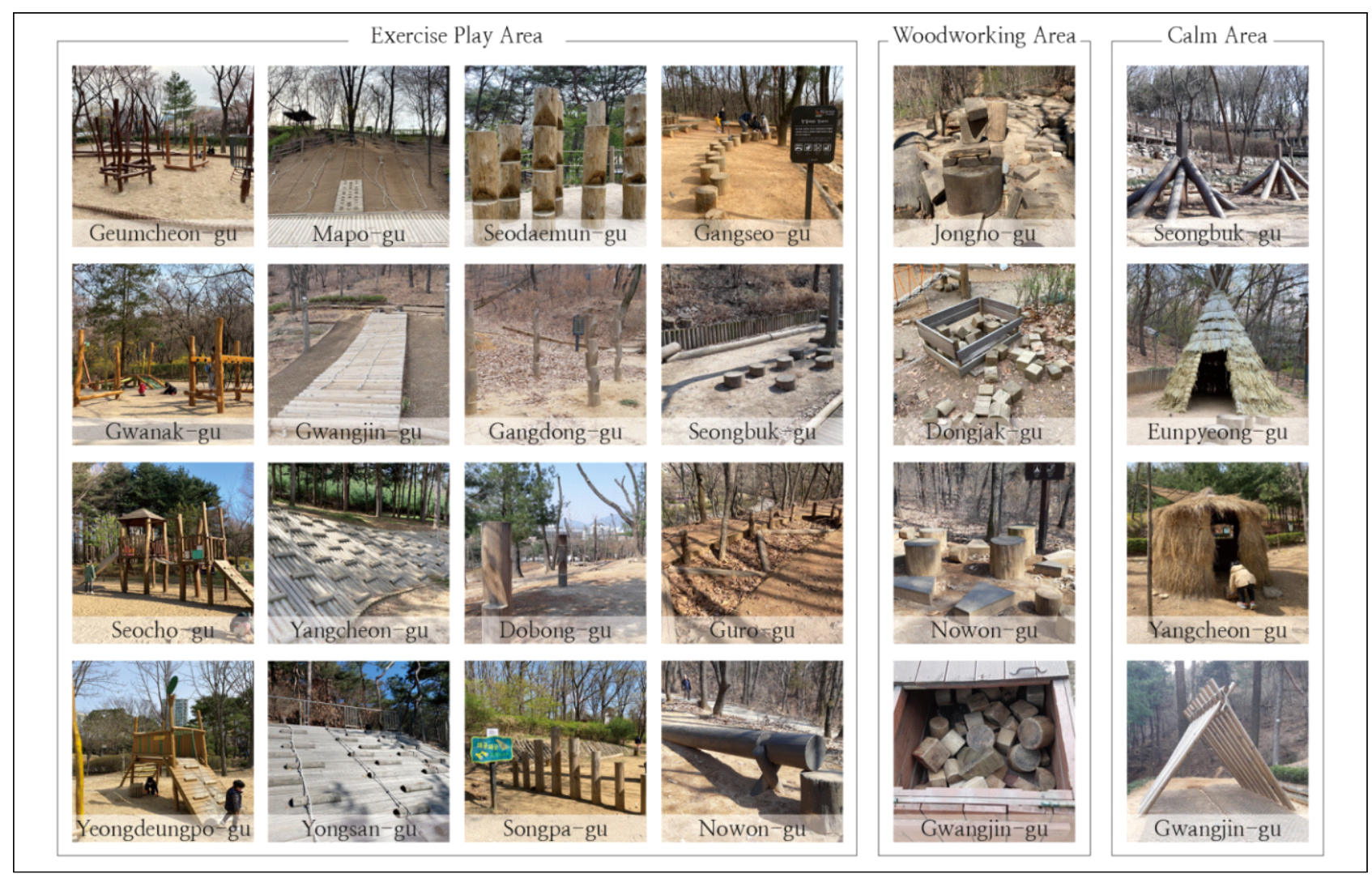

Figure 2. Classification of type by composition of outdoor play area

문가 관점에서 보다 현실적으로 유아숲체험장을 바라볼 수 있 었다. 전문가 인터뷰 결과는 이론 고찰을 통해 정리한 유아교 육기관 교사와 유아숲지도사의 이용 경험과 매우 비슷하였다.

\section{1) 공간}

유아교육기관 교사와 유아숲지도사 모두 유아가 솦체험을 통해 직접 몸으로 자연을 느끼기를 바랐다. 추구하는 유아 숲 체험의 내용과 방향은 같았으나 유아숲체험장의 물리적 현황 과 놀이 시설물에 대하여 서로 다른 견해를 가지고 있었다.

유아교육기관 교사는 시설물이 없는 자연 공간을 선호하였 으며, 현재 서울시 유아숲체험장은 놀이 재료로 활용할 수 있 는 비구조적 자연물이 거의 없이 다소 인위적으로 조성되었다 고 보았다. 놀이 시설물은 유아가 집중력을 잃지 않고 수업에 참여할 수 있도록 돕는 역할을 하기 때문에 유용하다고 보았으 나 반드시 필요하다는 입장은 아니었다.

이와 반대로 유아숲지도사는 놀이 시설물이 반드시 필요하 다고 하였다. 유아의 숲체험을 계획하고 지도하는 입장에서 유 아가 자연 체험을 시작하는데 놀이 시설물이 큰 역할을 하기 때문이다. 숲이 낮선 유아는 익숙한 시설물 놀이로 시작해 숲 의 재료와 생명을 스스로 발견하는 과정에서 숲에 적응하고 흥 미를 갖는다. 또한 야생에 가까운 환경일수록 유아숲지도사는
유아의 안전에 대한 부담이 매우 커진다. 보이지 않는 위험 요 소가 많은 야생숲에서 교사는 유아의 행동을 제한하고 규칙을 세우게 된다. 인공적인 시설이 많은 규격화된 공간일수록 아이 들의 자유로운 활동이 보장되는 것이다. 시설 위주로 조성된 현황을 마냥 부정적으로 평가할 수 없는 이유이다.

또한 관리적 측면을 반드시 고려해야 한다. 자연물 그대로를 시설물의 재료로 사용하거나 교구로 활용한다면 시설 유지 및 위생 관리나 유아의 안전 보장이 매우 어려워지기 때문이다. 서울시 유아숲체험장은 공공 공간으로서 관리의 용이성, 경제 성, 효율성이 고려되어야 한다.

\section{2) 체험 프로그램}

솦체험 프로그램과 기타 운영 사항에 대해서는 유아교육기 관 교사와 유아숲지도사의 의견이 비슷하였다. 유아 주도성이 높은 놀이가 중요하며 지도사와 교사는 유아의 창의력과 호기 심을 넓혀주는 조력자 역할을 해야 한다. 교사의 적절한 답변 과 질문을 통해 숲체험 효과가 높아질 수 있다는 점에서 교사 의 역량이 매우 중요하다. 또한 현행법상 유아 25 명 이하 참여 시 유아숲지도사 1 명이 배치되기 때문에 숲체험 효과를 높이기 위해서 유아교육기관 교사의 협력이 중요해진다. 


\section{V. 개선 방안}

\section{1. 유아수페험장 유형별 공간 개선 방안}

서울시 유아숲체험장은 위치적 특성과 공간 구조에 따라 6 가지 유형으로 분류된다. 유형별 특징을 이해하고 이를 강조하 거나 보완함으로써 공간을 개선할 수 있다. 먼저 평지형 유아 숲체험장은 활용할 수 있는 자연 지형이나 재료가 충분하지 않 고 일반 근린공원처럼 깨끗하게 관리되는 경우가 많다. 유아숲 체험장 위치 선정 시 수목이 우거진 곳, 수종이 다양한 곳을 우 선적으로 고려하여 숲체험 공간으로 활용한다. 비교적 안전사 고의 부담이 적으므로 유아가 적극적으로 뛰어놀며 감각할 수 있는 자연 재료의 절대적인 비중 확대가 필요하다. 낙엽, 열매 등을 치우지 않는 관리방식이 필요하고, 유아가 뛰고 넘어지고 앉고 놀이하면서 숲에 익숙해지도록 흙 포장, 물모래 놀이장, 그루터기를 조성한다.

산지형 근린공원은 자연환경을 그대로 이용할 수 있다는 점 에서 숲체험에 가장 유리하나 평지 확보가 어려울 수 있다. 산 림청 매뉴얼에는 평지를 2곳 이상 확보할 것을 언급하고 있으 나 이는 권고사항으로, 법률에 근거한 조건에 부합할 경우 평 지 확보 여부에 관계없이 유아숲체험장 조성이 가능하다. 그러 나 고정 시설물이 없고 시야가 완전히 확보된 평지는 소도구를 활용한 신체 놀이와 자연물과 교구를 사용하는 목공놀이, 모여 앉아 진행하는 정적인 활동, 자유 놀이와 휴식 등 모든 활동이 이뤄질 수 있는 공간이기에 반드시 필요하다. 하차 지점에서 가까운 곳에 평지를 확보하여 숲체험을 시작하고 마무리하는 공간으로 활용해도 좋고 체험장 입구를 지나 숲 곳곳에 평지를 확보하여 체험장 특징에 따라 실외놀이공간 구성 영역을 지정 하여도 좋다. 체험장 위치 선정 시 완만한 경사지를 고려해볼 수 있으며, 절토로 인해 생긴 단차는 경사 오르기 시설이나 추 가 식재를 위한 공간으로 활용 가능하다.

야외체험학습장의 배치에 따라 응집형, 분산형으로 구분했 으나 응집형 유아숲체험장 수업에서도 등산로를 활용하여 산 행을 하기 때문에 두 유형의 차이는 숲길이 체험장 영역으로 지정되었는가에 불과하다. 유아숲체험장 위치 선정 시 가까이 에서 자연 재료를 관찰할 수 있는 완만한 동선을 파악하여 주 변에 체험장을 조성하고, 체험장 내 새로운 소로를 정비하여 온전히 유아만의 공간이 될 수 있는 야생성 높은 숲길을 제공 할 수 있다. 체험장이 위치한 근린공원의 시설을 활용하는 동 선 계획 또한 중요하다. 이는 수업을 진행하는 유아숲지도사의 재량에 따르기도 하지만 공간 조성단계부터 각 코스별 난이도 를 파악하여 연령별, 수준별 숲체험이 이뤄질 수 있도록 공간 을 계획하거나 새로운 숲 공간을 발굴하여 다양한 숲체험 프로 그램이 이뤄질 수 있도록 한다.
혼합형 유아숲체험장의 경우 산지형과 평지형의 이점을 모 두 가지고 있어 7가지 요소에 대한 현황 평가 결과가 매우 좋 았다. 평지형, 산지형 유아숲체험장의 개선 방안을 혼합형에도 적용한다면 더 풍부한 숲체험을 제공할 수 있을 것이다.

현장조사연구 결과, 같은 유형, 같은 시설물, 같은 프로그램 이 제공되더라도 유아숲체험장의 환경적 특징에 따라 숲체험 의 효과는 달라질 수 있다. 숲체험의 효과를 높이는 모든 물리 적 조건을 하나의 유아숲체험장이 갖추기는 어렵다. 유아숲체 험장이 조성되는 근린공원의 위치적 특징과 자연환경적 조건, 기존 공원 시설의 현황이 각기 다르기 때문이다. 숲체험 효과 를 높이는 개별 유아숲체험장의 강점을 드러내야 한다.

\section{2. 숲체험 매개체로서 시설물의 배치}

유아숲체험장의 놀이 시설물은 유아가 쉽게 숲에 적응할 수 있도록 돕는 매개체가 되어야 한다. 숲이 낮선 유아는 땅에 떨 어진 잎과 열매, 흙, 곤충에 대한 호기심보다 두려움이 크다. 유 아는 익숙한 시설물 놀이를 통해 숲에 가까워지고 유아 스스로 자연물 놀이를 시작하며 숲에 적응한다. 놀이 시설물이 유아와 숲 사이의 매개체가 되기 위해서는 언제든 유아의 시선이 놀이 시설물에서 그 옆의 자연물로 옮겨질 수 있도록 풍부한 자연 재료가 제공되어야 한다. 다음은 시설물 배치를 조정한 공간 개선 방안의 예이다.

성동구 대현산 유아숲체험장의 경우 놀이 시설물은 체험장 가장 안쪽, 모래 놀이장은 체험장 가운데, 낙엽 놀이장은 체험 장 입구에 조성되어 있다. 서로 다른 성격의 세 가지 놀이가 공 간적으로 분리되어 있어 시설 놀이가 모래, 낙엽 놀이와 같은 자연물 놀이로 이어지지 못한다(Figure 3 참조). Figure 4 와 같 이 모래 놀이장을 확장하고 놀이 시설물을 모래 놀이장 안에 배치하여 시설 놀이가 모래 놀이로 연결되도록 한다. 또한 보 관함에 낙엽을 모아두지 않고 체험장 곳곳에 낙엽을 쌓아두어 유아가 뛰놀며 낙엽을 놀이의 재료로 사용하도록 한다.

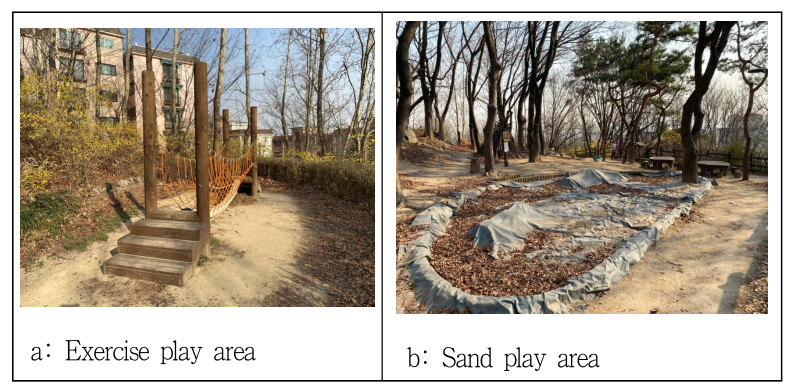

Figure 3. Present condition of Daehyeonsan forest visitor centers 


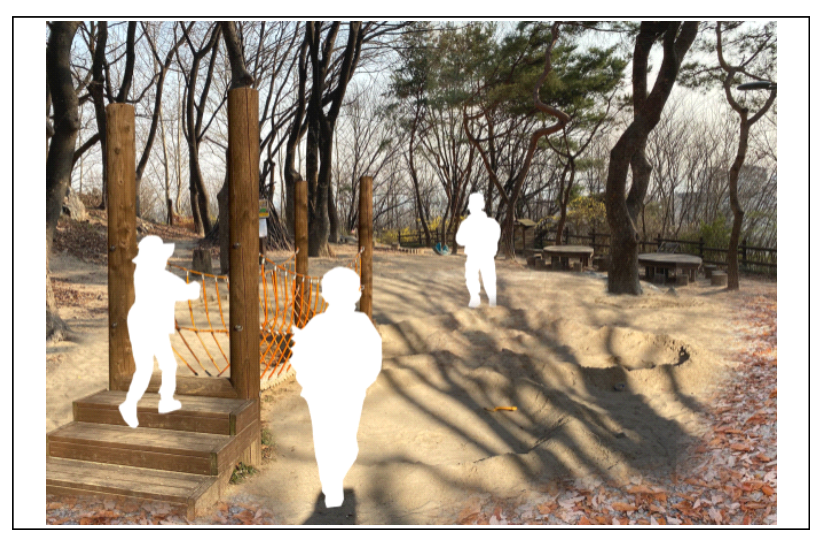

Figure 4. Improvement example for Daehyeonsan forest visitor centers

강서구 꿩고개 유아숲체험장은 답압이 매우 심한 흙 포장 위 에 시설물이 설치되어 있다. 물·모래 놀이장, 목공 놀이장이 따로 조성되어 있지 않아 시설물 놀이에서 자연물 놀이로 연결 될 수 있는 환경의 조성이 필요하다(Figure 5 참조). Figure 6 과 같이 한 단을 모래놀이장으로 조성하고 그루터기를 설치해 놀이 공간과 목공 놀이장으로 활용한다. 경사지에 계단형으로 조성되어 유아가 평지에 서서 식물을 관찰할 수 있는 적당한 단차가 있으므로 다년생 야생화를 식재하여 숲체험의 폭을 넓 힌다.

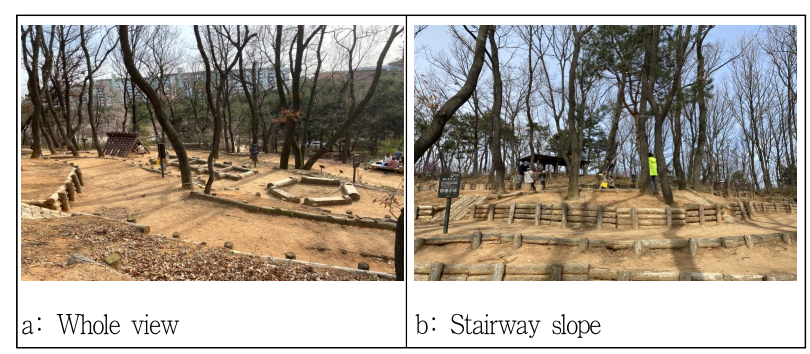

Figure 5. Present condition of Kwonggogae neighborhood park forest visitor centers

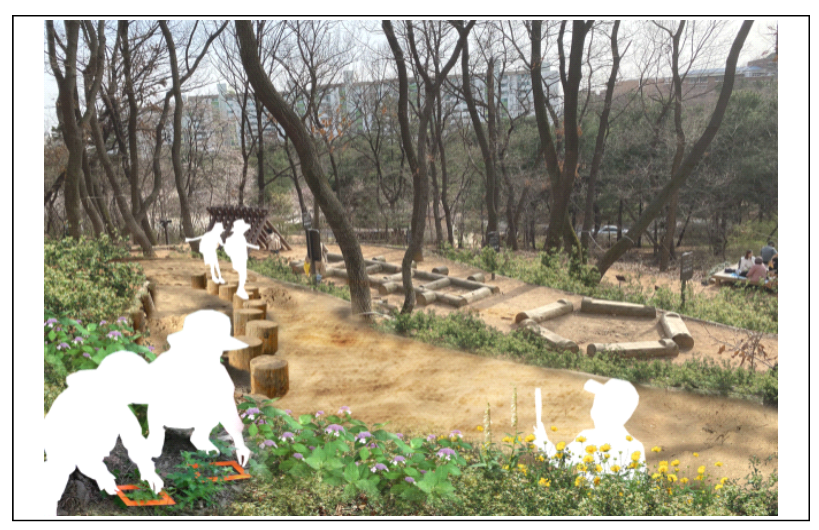

Figure 6. Improvement example for Kwonggogae neighborhood park forest visitor centers
강남구 대모산 유아숲체험장은 자연환경이 매우 풍부하나 신체 발달 위주의 놀이 시설물로만 구성되어 있다(Figure 7 참 조). Figure 8과 같이 역할 놀이를 위한 움집, 나무 쌓기 놀이 를 위한 교구를 마련하고, Figure 9와 같이 자유 놀이를 위한 평지를 확보하여 영역별로 고르게 배치하고 유아의 다양한 놀 이 행태를 유도한다.

\section{V. 결론}

서울시 유아숲체험장은 공공 산림교육시설로서 모든 유아에 게 양질의 숲체험 기회를 제공해야 한다. 유아의 전인적 성장

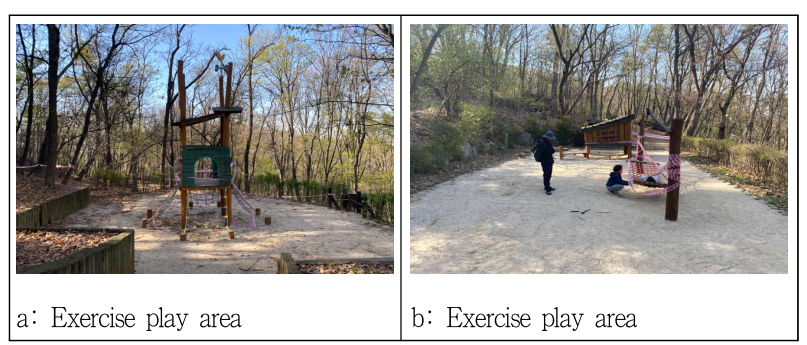

Figure 7. Present condition of Daemosan forest visitor centers

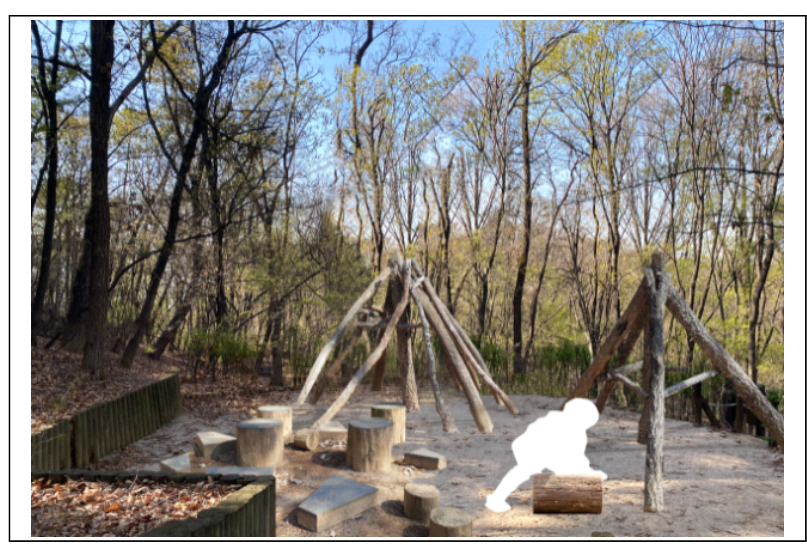

Figure 8. Improvement example for Daemosan forest visitor centers

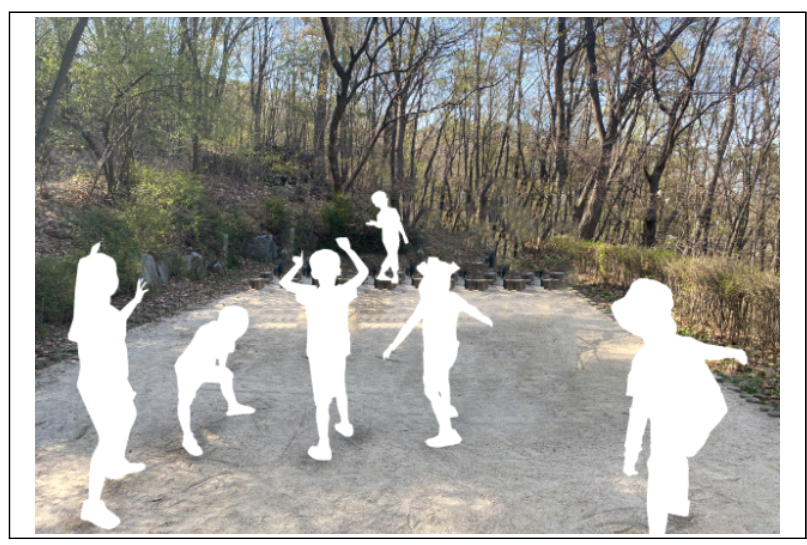

Figure 9. Improvement example for Daemosan forest visitor centers 
은 숲이라는 새로운 환경에서 유아가 스스로 놀잇감을 찾고 창 의적인 놀이 방법을 터득하는 과정에서 이뤄진다. 유아숲체험 장은 숲이라는 환경에 특정 시설이 설치됨으로써 완성되는 것 이 아니라 숲이라는 환경 자체에서 유아가 자유롭게 놀이할 수 있는 공간이 되어야 한다.

본 연구는 서울시 유아숲체험장이 시설 위주로 조성되고 있 다는 문제의식에서 시작되어 서울시 유아숲체험장의 현황을 종합적으로 평가하고, 숲체험 효과를 높이기 위한 공간 개선 방안을 제시하였다. 이론 고찰을 통해 유아와 숲체험의 개념, 숲체험 효과를 높이는 공간 구성, 이용 주체의 경험을 정리하 였고, 이를 바탕으로 현장조사연구를 위한 분석 표를 작성하였 다. 현장조사연구는 서울시 유아숲체험장 24곳을 대상으로 물 리적 현황을 파악하였고, 전문가 인터뷰를 통해 유아교육학 관 점에서 물리적 현황을 살펴보았다.

유아의 지적 능력은 외부 자극을 수용하는 감각 활동과 자극 에 반응하는 동작 활동을 통해 발달된다. 따라서 숲체험의 효 과는 유아가 숲에서 다양한 자연 요소를 온몸으로 느끼고 직접 적으로 경험함으로써 발현된다. 8세 미만의 유아는 전문지식을 아는 것보다 만지고 냄새 맡아보는 것이 중요하다. 유아의 숲 체험은 놀이와 체험만으로 충분한 숲체험 효과를 기대할 수 있 으며, 자연 재료가 충분히 제공되는 숲에서 유아가 주도하는 놀이로서 숲체험에 접근할 때 교육적 효과는 극대화된다. 이러 한 관점에서 시설 위주의 유아숲체험장은 유아 숲체험의 본래 취지에서 멀어진 인위적 공간으로 보인다.

서울시 유아숲체험장은 위치적 특성과 공간 구조에 따라 6 가지 유형으로 분류된다. 조성 위치에 따라 평지형과 산지형, 두 가지 특징을 모두 갖는 혼합형으로 나뉘며 공간 구조와 체 험 공간의 배치에 따라 응집형과 분산형으로 분류된다. 서울시 유아숲체험장은 각 유형별 특징을 갖는 동시에 숲체험 효과를 높이는 개별 유아숲체험장만의 특징을 갖는다. 개별 유아숲체 험장의 입지 조건과 강점을 파악하여 이를 공간과 프로그램으 로 풀어냄으로써 숲체험 효과를 높일 수 있다.

야외체험학습장의 경우 전반적으로 운동놀이 영역의 비중이 컸다. 물리적 구성만으로 숲체험의 효과를 단정 지을 수는 없 으나 유아 발달 영역을 고려하여 균형 있게 놀이 영역을 구성 함으로써 유아가 경험할 수 있는 숲체험의 범위가 넓어진다. 개별 시설물의 형태는 체험장 간의 구분이 어려울 정도로 획일 적이나 이를 솦체험 효과를 낮추는 단편적인 요인으로 볼 수는 없다. 창의적인 활동을 유도하여 숲체험 효과를 높이는 핵심은 주변 자연환경을 고려한 공간 구성이다. 시설물은 유아의 관심 이 숲으로 옮겨가도록 돕는 매개체가 되어야 한다. 놀이 시설 물에서 시작된 활동이 숲에 대한 자발적인 호기심으로 이어졌 을 때 원활한 숲체험이 가능함을 공간 설계 시 반드시 고려해 야 한다.
본 연구는 유아숲체험장 유형별 공간 개선 방안과 시설물이 숲체험 매개체로 기능할 수 있는 배치 방안을 3 곳의 유아숲체 험장을 사례로 들어 제시하였다. 숲체험 효과를 높이는 공간 요소를 도출하여 서울시 유아숲체험장의 평균적인 물리적 현 황을 평가하고, 전문가 의견을 반영하여 개선 방안을 제시하였 다는 점에서 서울시 유아숲체험장 질적 수준 향상을 위한 연구 에 기초 자료로 활용될 것을 기대한다. 그러나 숲체험 효과 증 진을 위해서는 체험 프로그램에 대한 고민이 함께 이뤄져야 한 다. 교사와 지도사, 유아 모두가 온전히 수업에 집중할 수 있도 록 인력 지원과 시설 및 안전 관리에 대한 제도적 개선이 반드 시 필요하다. 본 연구의 결론은 물리적 개선 방안만 제시했다 는 점에서 한계가 있다. 또한 연구를 진행한 시기에 유아숲체 험장 정기 수업이 열리지 않아 수업 참관을 하지 못하여 가족 단위 이용객의 이용 행태만을 관찰했다. 유아숲체험장의 가장 중요한 이용자인 유아의 의견을 직접 반영하지 못하고 공급자 관점에서 연구 결론을 도출한 한계가 있다. 향후 이용자 관점 의 연구와 공간, 프로그램, 운영 측면의 다학제적 연구로의 발 전이 필요하다.

주 1.「산림교육의 활성화에 관한 법률」 제 4 장 제 12 조(유아숲체험원의 등 록 등) (1) 유아가 산림의 다양한 기능을 체험함으로써 정서를 함 양하고 전인적 성장을 할 수 있도록 지도·교육하는 시설(이하 “유아숲체험원”이라 한다)을 조성·운영하려는 자는 대통령령으 로 정하는 기준에 적합한 시설과 인력을 갖추어야 한다.

주 2. 서울시는 2011년부터 관악산 도시자연공원 청룡산지구, 우장근린공 원, 응봉근린공원 유아숲체험장 세 곳을 자체적으로 운영했다. 2012 년 산림교육법이 제정되었을 때 유아숲체험원으로 명칭을 통일하지 않고 유아숲체험장으로 단일 운영하다가 2019년부터 대규모 유아숲 체험원과 중규모 유아숲체험장으로 나눠 25개를 추가 조성하겠다는 계획을 세웠다(Seoul, 2017). 법률상 유아숲체험원으로 명칭을 통일 하였으나 실제로는 혼용된다.

주 3. 아동이 능동적으로 어떤 것을 만들기 위하여 사물을 창의적으로 조 작하는 놀이(Korea National Institute for Special Education, 2009).

주 4. 야외체험학습장은 산림교육의 활성화에 관한 법률 시행령 [별표 3] 에 따라 숲체험, 생태놀이, 관찰학습 등을 할 수 있는 공간으로서 그 규모는 유아숲체험원 전체 규모의 $30 \%$ 이상이어야 한다. 산림청 매 뉴얼에 의하면 야외체험학습장은 공간의 개념으로 반드시 인위적인 시설물이 있는 면적만을 의미하지 않으며, 활동 공간으로 구획된 면 적을 의미한다(Korea Forest Service, 2014).

주 5. Kang(2015)은 서울시 유아숲체험장 12 곳을 현장답사하여 공간의 배 치형태, 주민 접근성, 활동 특징을 표로 정리하였다. 공간배치형태에 따라 응집형과 연결형, 환경적 특징에 따라 산악형과 산지형, 공원형 으로 구분하였다.

주 6. 역할, 사물, 행동 및 언어의 가작화(假作化)가 이루어진 놀이로서, 사 물이나 행동을 다른 사물이나 행동으로 상징화할 수 있는 능력(Kim et al., 2016).

\section{References}

1. Choi, M. W. and H. R. Byun(2006) Comparative study on the satisfaction and actual conditions of playgrounds in kindergartens and child care centers in Daejeon. Korean Journal of Human Ecology 
$15(4): 527-539$

2. Choi, M. W., S. H. Son and H. S. $\operatorname{Lim}(2010)$ A case study of two child-care centers to encourage outdoor play environments and play programs in Daejeon. Korean Journal of Human Ecology 19(5): 775-794.

3. Ham, M. R.(2016) A Study on the Safety of Forest Experience Centers for Children Experienced by Early Childhood Teachers: Focussing on Seoul City. Master's Thesis. Sookmyung Women's University, Korea.

4. Han, Y. J.(2020) Teacher's Perception and Improvement Plan for the Child Forest Experience Center. Master's Thesis. Chung-Ang University, Korea.

5. Heo, H. J.(2016) A Study on Difficulties and Rewarding Experiences of Early Childhood Forest Instructors in Forest Kindergarten. Master's Thesis. Pusan National University, Korea.

6. Jang, H. B.(2015) Outdoor Play Preference of Children Based on Gender or Age at Kindergarten. Master's Thesis. Ewha Womans University, Korea.

7. Jin, B. N.(2005) Research the Variety of Reactions Wood Working during Outdoor Play Time. Master's Thesis. Ewha Womans University, Korea.

8. Kang, T. S. (2015) An Analysis of the Importance \& Performance and Children's Attentiveness by the Forest Experience Center for Children : Cases in Seoul and Geumcheon-gu District, Korea. Ph. D. Dissertation. Jeonbuk National University, Korea.

9. Kang, T. S.(2019) A study on deriving process of a design alternative to the forest experience center for children through preschooler participatory. Journal of the Korean Institute of Landscape Architecture 47(5):1-13.

10. Kim, A. Y.(1997) A Study on the Design Prototype of Day-care Center Playground. Master's Thesis. Seoul National University, Korea.

11. Kim, C. K., S. Y. Lee, Y. J. Lee, J. J. Jeong and W. Y. Choi(2016) (A) Counseling Dictionary. Seoul: Hakjisa Publications.

12. Kim, E. S. (2010) A Study on the First Forest-Kindergarten Education in Korea. Ph. D. Dissertation. Incheon National University, Korea.

13. Kim, K. L.(2003) The Plan and Design of Environmental Experience School for Infants. Master's Thesis. Seoul National University, Korea.

14. Korea Forest Service(2014) Manual for the Creation and Operation of the Infant Forest Experience Center for the Promotion of Forest Education.

15. Korea National Institute for Special Education(2009) Special
Educational Terminology Dictionary. Seoul: Hawoo Publications.

16. Kwon, Y. K.(2012) Plan and Design Guidelines for Forest Kindergarten: Using the Forest near. Seoul National University. Master's Thesis. Seoul National University, Korea.

17. Lee, D. H.(2017) A Study on the Space Composition and Operation of the Experience Park for Preschooler. Master's Thesis. Dankook University, Korea.

18. Lee, E. H., J. H. Lee, K. W. Lee, K. S. Lee, Y. H. Hong, E. H. Park and H. J. Kim(2001) Introduction to Early Childhood Education. Seoul: Ewha Womans University Press.

19. Lee, H. J.(2000) A Study on the Preference of Children for Outdoor Play Equipment and Children's Play Behaviors according to the Outdoor Play Equipment. Master's Thesis. Chung-Ang University, Korea.

20. Lee, J. N.(2014) An Analysis of Satisfaction on Forest Kindergarten Program. Master's Thesis. Kyung Hee University, Korea

21. Lee, K. M.(2012) The Influence of Forest Experience Activities upon Children's Emotional Intelligence. Master's Thesis. Duksung Women's University, Korea

22. Lee, M. H.(2003) The forest kindergarten in Germany. Korean Journal of Early Childhood Education 23(4):23-48.

23. Lim, E. J. and N. U. Kwak(2015) Adaptation process of young children to outdoor activities in the forest. Journal of Holistic Convergence Education 19(1):121-149.

24. Ministry of Education(2013) Kindergarten Evaluation Central Training.

25. Moon, H. Y.(2003) A Study on Children's Play Preference in Their Interest Centers. Master's Thesis. Chung-Ang University, Korea.

26. Seo, Y. M.(2015) Theory and Practice of Early Childhood Forest Experience Education. Seoul: Changjisa Publications.

27. https://stdict.korean.go.kr/

28. https://www.seoul.go.kr/news/news_report.do \#view/204216

29. www.latimes. $\mathrm{kr} / \mathrm{news} / \mathrm{articleView} \cdot \mathrm{html}$ ?idxno $=32175$

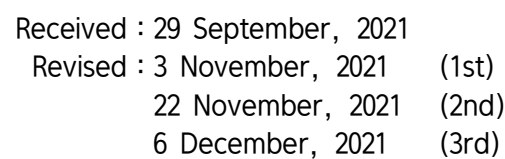

Accepted : 6 December, 2021 3인익명 심사필 